\title{
Evaluating the influence of noise emitted by environmental enrichment equipment in routine farrowing management practices
}

\author{
Avaliação da influência do ruído ambiental emitido por enriquecimento físico e suínos em práticas \\ de rotina exercidas na fase de maternidade
}

\author{
Gisele Dela Ricci ${ }^{1 *}$, Rafael Teixeira de Sousa ${ }^{2}$, Késia Oliveira da Silva Miranda ${ }^{1}$, Elder Tonon ${ }^{1}$, Ana \\ Laura Alves de Matos Passere ${ }^{1}$, Cristiane Gonçalves Titto ${ }^{1}$
}

\author{
1'Universidade de São Paulo, Pirassununga, SP, Brasil. * Author for correspondence: giseledelaricci@usp.br \\ ${ }^{2}$ Instituto Federal de Educação, Ciência e Tecnologia do Ceará, Boa Viagem, CE, Brasil.
}

Submission: 02/08/2019 / Acceptance: 01/07/2020

\begin{abstract}
The installation of fans and rooftop sprinklers in swine housing and management facilities can increase noise intensity and may impair workers' hearing health over longs periods of time; therefore, an assessment of the piglets' stress during invasive practices was made. This study set out to evaluate the noise intensity emitted by environmental enrichment devices (fans and rooftop sprinklers) and by piglets restrained for body temperature assessments and its effect on animal welfare and on the hearing health of workers exposed to it for long periods. Twenty piglets ranging in age from five to twenty days were observed. The sow gestation area was divided into a cooled (fans and rooftop sprinklers) and uncooled area. Two decibel meters were used to measure noise intensity, one for the general noise in the facilities and the other for the piglets, with five-minute intervals between assessments. Digital thermometers were used to take the rectal temperature, and infrared thermometers were used to take the body surface temperature. Fixed-effects ANOVA for the housing environment and periods and multiple comparisons at a significance level of $5 \%$ were applied. The average dorsal temperature of the piglets was $36^{\circ} \mathrm{C} \pm 1.2$ in the cooled area and $38.4{ }^{\circ} \mathrm{C} \pm 0.5$ in the uncooled area. In both periods, the average maximum noise intensity was over 100 decibels. In the afternoon, the maximum intensity was higher for the uncooled environment. The results indicate that neither the fans nor the rooftop sprinklers installed in the facilities nor the squealing piglets during restraint affect the noise intensity of the environment. However, the noise intensity demonstrates the piglets' stress and the need for protective equipment to preserve the workers' hearing health.
\end{abstract}

KEYWORDS: rooftop sprinklers, decibel meter, swine, rectal temperature, surface temperature, fans.

\section{RESUMO}

A inserção de ventiladores e aspersores de água no telhado assim como o manejo de contenção de suínos podem aumentar a intensidade de ruídos dentro das instalações podendo, em longos exposições, prejudicar a saúde auditiva dos funcionários, permitindo a avaliação do estresse de leitões após práticas invasivas. O objetivo deste estudo foi estimar a intensidade do ruído emitido por enriquecimentos ambientais físicos (ventiladores e aspersores de água no telhado) e de leitões contidos para colheita da temperatura corporal e a influência dos ruídos emitidos na saúde auditiva de funcionários expostos por longos períodos e no bem-estar animal. Vinte leitões machos e fêmeas foram utilizados, com idades entre cinco e 20 dias. A área de maternidade foi dividida em resfriada (ventiladores e aspersores de água no telhado) e área não resfriada. Para a análise da intensidade do ruído foram utilizados dois decibelímetros, sendo um para o ruído geral das instalações e um para os leitões, com cinco minutos de intervalo entre as análises. Para mensurar a temperatura retal foram utilizados termômetros digitais e para as temperaturas superficiais corporais termômetros infravermelhos. Utilizou-se ANOVA com efeito fixo de ambiente e período e comparação múltipla em $5 \%$. A temperatura média do dorso dos leitões foi de $36{ }^{\circ} \mathrm{C}$ $\pm 1,2$ na instalação refrigerada e $38,4{ }^{\circ} \mathrm{C} \pm 0,5$ no ambiente não refrigerado. Em ambos os períodos, a intensidade média máxima de ruído foi maior que 100 decibéis. No período da tarde, a intensidade máxima foi maior para o ambiente não refrigerado. Concluiu-se que os ventiladores e aspersores de água no telhado instalados no local não influenciaram a intensidade do ruído ambiental, assim como o grito emitido pelos leitões durante a contenção. No entanto, a alta intensidade do ruído emitido demonstra o estresse dos leitões e a necessidade de equipamentos de proteção pelos funcionários para manutenção 
da saúde auditiva.

PALAVRAS-CHAVE: aspersores de água, decibelímetro, suínos, temperatura retal, temperatura superficial, ventiladores.

\section{INTRODUCTION}

In the agricultural industry, there are important risks to the workers' psychological and physical integrity which may have a significant impact on their health and generate losses for companies (MARCHANT et al. 2001). Based on specific research, the Ministry of Labor and Employment regulates the levels of risk to ensure greater comfort and safety and improve employee welfare and efficiency, with important penalties for companies that do not comply with Brazilian regulations (BRAZIL 2000).

Noise can be described physically as unpleasant, undesirable sounds that generate nuisances and neuroses which compromise the physical and psychological health of individuals and may cause irreversible hearing impairment at certain levels (PMAC 1994). According to the World Health Organization (WHO), noisy environments impair human performance and prompt health issues, notably behavioral changes such as fatigue, stress reactions, anxiety, irritability, and memory disorders (WHO 1999).

Studying noise in indoor acoustic environments requires understanding of geometric, acoustic, and architectural aspects, including forms of acoustic coating, orientation, and available openings (GONÇALVES et al. 2009).

In animal husbandry, confinement is necessary in managing separation by weight, age, sex, identifications, clinical examinations, specific treatments for diseases, and transportation. Confinement can be performed by physical or chemical means. The former is described as the confinement or restriction of animals without the use of chemical substances in order to prevent their movement and escape and to facilitate safe handling for specific measurements (COLEMAN \& HEMSWORTH 2014). The latter involves chemical confinement through the use of tranquillizers or anesthetics, which are normally used to capture aggressive or distressed animals (GIRALT 2002), usually in closed areas with or without air conditioning.

Ways to reduce noise during animal handling and the consequent damage are necessary, and the provision of hearing protection is one of the most common ways to resolve these issues (VIEIRA 1997). However, reducing the noise level at the source is more feasible, while it contributes to the constant improvement of the environment (MARQUES et al. 2016).

Given the importance of a noise assessment in swine facilities when piglets are restrained for physiological measurements, this study set out to determine the noise intensity of piglets subjected to management practices under confinement in a cooled and an uncooled environment and its impacts on the workers' hearing health and the pigs' welfare.

\section{MATERIAL AND METHODS}

The study was conducted at the sow gestation facilities of the swine sector on the Fernando Costa Campus at the University of São Paulo in Pirassununga, São Paulo. The site is located at an altitude of 340 meters, and its geographical coordinates are $21^{\circ} 80^{\prime} 00^{\prime \prime} \mathrm{S}, 47^{\circ} 25^{\prime} 42^{\prime \prime} \mathrm{W}$. According to the KÖPPEN (2011) climate classification, the region has a Cwa climate with average annual minimum and maximum temperatures of $13{ }^{\circ} \mathrm{C}$ and $31^{\circ} \mathrm{C}$ and a north-south orientation. This study was approved by the Ethics Committee on the Use of Animals CEUA №. 3758260116 of the Faculty of Animal Science and Food Engineering at the University of São Paulo.

A semi-confinement system of individual stalls for the sow and litter was adopted. The stalls were 1.80 meters wide and 4.20 meters long. The cement flooring was partially covered with a bedding of resistant sugarcane bagasse that was 3.20 meters in length. The stalls had nipple drinkers for the sows and piglets and a type of feeding trough for the piglets and a concrete feeding trough for the sows. There was a creep with a lamp to heat the piglets and a barrier that was 1.65 meters high separating them from the sow in the stall. An opening that was 0.5 meters high and 0.3 meters wide allowed access only to the piglets. Each stall had two hanging metal chains for the sow's and piglets' enrichment. The facilities had a height of 2.70 meters, a roof made of ceramic tiles and wood, and a concrete floor.

The sow gestation facilities were divided into cooled and uncooled areas. In the cooled treatment, fans were installed in the stall. The Ventisol fans had a diameter of 60 centimeters and three blades, with 1/5HP $147 \mathrm{~W}$ and maximum of $1200 \mathrm{rpm}$. One fan was used for every two sows and their respective litters at a height of 1.80 meters above the floor and was affixed to the abutment of the stalls. The TRIPP-DY-1013 
sprinkler was used to water the roof and was affixed to the wall so that the water covered the entire roof. One sprinkler was used for every three stalls. The fans and sprinklers were switched on at 6 am and switched off at $5 \mathrm{pm}$ and remained off during the night throughout the whole experimental period. For the uncooled treatment, the stalls had the same dimensions but no cooling equipment was installed. The facilities were separated by plastic sheeting as a form of sealing.

Twenty piglets between the ages of five and twenty days were involved in the study. They had a mean final weight of $5 \pm 0.7 \mathrm{~kg}$ and were weaned at 21 days. Ten Landrace $\times$ Large White F1 females were mated to MS115-Embrapa males to produce the piglets at the farrowing age between one and two.

The piglets were restrained by a trained handler. The handler would restrain the piglet with their left hand on the abdomen while its legs faced down and its head was supported by the handler's right hand, in an attempt to take the piglet's temperature in a more comfortable position.

A decibel meter was used to analyze the noise made by the animals. It was placed ten centimeters away from the piglet as it was individually evaluated, with an interval of five minutes between the animals, the amount of time it would take another handler to collect rectal temperatures with a digital thermometer and dorsal and ventral temperatures with an infrared thermometer. Noise data was collected two times per assessment period, once before the temperature assessment and once again at the end, resulting in two recordings in the morning and two in the afternoon over nine days of analysis.

In order to measure noise intensity in the facilities, a decibel meter was installed in the wall at a height of 1.80 meters. As the piglets' temperatures were taken, the decibel meters were placed near the handlers so that they would capture the noise made by all the litters and sows in the facility (general noise).

Temperature assessment was timed by a stopwatch, from the beginning to the end of each assessment for the animals in the cooled and uncooled facilities.

Rectal temperatures were taken with the Bioland flexible digital thermometer in the morning and afternoon $(6 \mathrm{am}$ and $1 \mathrm{pm})$ at times of the day when temperatures were warmer. Dorsal surface temperatures were taken with the Laser infrared thermometer at a maximum distance of $0.5 \mathrm{~m}$. The thermometer ran over the dorsal area at least five times in a temperature sweep to ensure the average temperature of the surface.

Meteorological variables such as air temperature, relative humidity, and black globe temperature were recorded every 15 minutes with a data logger (Onset $\mathrm{HOBO}^{\circledR} \mathrm{TEMP} / \mathrm{RH} / 2$ ext channels) in the experimental stall placed in the center at a height of 1.5 meters above the floor. The device remained in place throughout the trial period for statistical analysis. Fixed-effects ANOVA was applied for the environment conditions and period (morning/afternoon), as well as a multiple comparison analysis at a $5 \%$ significance level in SAS.

\section{RESULTS}

The cooled environment registered an average temperature of $18.6{ }^{\circ} \mathrm{C}$ and $87.5 \%$ humidity, and the uncooled area had an average temperature of $27.2{ }^{\circ} \mathrm{C}$ and $81.3 \%$ humidity.

The installation of fans and rooftop sprinklers at the facilities did not significantly increase the noise level within them. It also did not lead to an increase in daily interactions or significantly enrich the pigs' environment $(p>0.05)$.

The amount of time it took to assess the piglets' rectal and body surface temperatures did not influence squealing intensity ( $p>0.05$ ). The average time for each temperature assessment was 15 minutes for the cooled facilities and 15.5 for the uncooled facilities ( $p>0.05)$.

The average rectal temperature found in the cooled area was $38.7^{\circ} \mathrm{C} \pm 0.7$, while in the uncooled area, it was $38.9^{\circ} \mathrm{C} \pm 0.5$ ( $\left.p>0.05\right)$. Measured with an infrared thermometer, the average dorsal surface temperature of the piglets in the cooled area was $36{ }^{\circ} \mathrm{C} \pm 1.2$ and $38.4{ }^{\circ} \mathrm{C} \pm 0.5$ for the piglets in the uncooled area $(p<0.05)$.

The maximum and minimum noise intensities found in the cooled and uncooled facilities were statistically equal $(p>0.05)$. In the afternoon, the maximum intensity was higher for the uncooled facilities $(p \leq 0.01)$, while the higher minimum intensity was registered in the cooled facilities ( $p>0.05$; Table 1$)$.

The data indicate that the piglets tend to exert higher maximum squealing intensities in the morning rather than in the afternoon. However, evaluations of the noise showed no significant effects related to the facilities' environments or to the morning and afternoon periods ( $p>0.05$; Table 2 ). 
Table 1. Maximum and minimum noise intensities in the facilities with fans and sprinklers (cooled) and without environmental enrichment (uncooled) during the morning and afternoon periods, without considering the effect of animal noise.

\begin{tabular}{ccccccc}
\hline \multirow{2}{*}{ Noise intensity } & \multicolumn{2}{c}{ Cooled Environment } & \multicolumn{2}{c}{ Non-cooled Environment } & \multicolumn{2}{c}{$\operatorname{Pr}>|\mathrm{t}|$} \\
\cline { 2 - 7 } & Morning & Afternoon & Morning & Afternoon & Morning & Afternoon \\
\hline Maximum & 129.6 & 116.5 & 124.9 & 121.2 & 0.19 & $0.01^{*}$ \\
Minimum & 90.6 & 86.5 & 90.7 & 86.2 & 0.86 & 0.97 \\
\hline
\end{tabular}

Significant values with $p<0.05^{\star}$.

Table 2. Maximum and minimum noise intensities emitted by piglets in cooled and uncooled facilities during the morning and afternoon, in decibels.

\begin{tabular}{|c|c|c|c|c|c|}
\hline \multicolumn{2}{|c|}{ Cooled Environment } & \multicolumn{2}{|c|}{ Non-cooled Environment } & \multicolumn{2}{|l|}{$\operatorname{Pr}>|t|$} \\
\hline Morning & & Afternoon & & \multirow{2}{*}{ Morning } & \multirow{2}{*}{ Afternoon } \\
\hline Maximum & Minimum & Maximum & Minimum & & \\
\hline 121.4 & 83.4 & 115.3 & 87 & 0.40 & 0.39 \\
\hline
\end{tabular}

Significant values with $p<0.05^{\star}$.

\section{DISCUSSIONS}

The temperatures found in the uncooled environment can lead to stress in farrowing sows. A temperature between $12^{\circ} \mathrm{C}$ and $18^{\circ} \mathrm{C}$ is recommended for farrowing sows (LEAL \& NÃ̃̃S 1992), and in this study, the cooled area registered a better environmental temperature for these animals. The temperature of the cooled environment is more satisfactory. Because of the sprinklers, humidity improved, and the water allowed for heat exchange whenever temperatures were above the thermal comfort zone. Higher temperatures are recommended for piglets in cool facilities, between $32{ }^{\circ} \mathrm{C}$ and $24^{\circ} \mathrm{C}$ in the first four weeks after birth (LEAL \& NÃÃS 1992).

In this study, the fans and rooftop sprinklers did not increase the noise in the facilities, but they decreased the temperature in the facilities. This result is particularly relevant given the concern that the acoustic environment may impair the pigs' behavior and the workers' health when exposed to high noise intensities over time and the importance of comfortable temperatures for farrowing pigs.

Because of the fans and sprinklers, the lower temperatures in the cooled area compelled the piglets to pile together and look for the creep area more often. To measure the rectal and body surface temperatures, the handlers remained inside the facilities for direct access to the animals. This may have favored the shorter amount of time for temperature assessment.

Sows housed in areas with water move around and lie in the water when the environmental temperature is high. In this study, the piglets accompanied the sows in the water, drank water from the sprinkler, learned to drink water from the nipple drinker with them, and engaged in playful activities, preferably in the afternoon. These activities may explain the lower dorsal temperatures in the cooled area. In the uncooled area, the animals remained intensely huddled together in their litters in different areas, including humid places.

Pigs are classified as diurnal animals; therefore, they tend to exhibit greater activity throughout the day. In this study, we found higher squealing intensities in the morning but statistical differences in the afternoon. A possible explanation may be related to the workers' handling practices, farm visits, bedding changes, and cleaning of facilities, which tend to distress the animals, who remain awake throughout the afternoon, unlike the morning, when they tend to sleep and feed without external and internal interference. According to CORDEIRO et al. (2012), pigs in comfortable conditions emit noise intensity values of 70.4 decibels. For $\mathrm{MOI}$ (2014), piglets in the pre-weaning phase that present intensities above $80.18 \mathrm{~dB}$ are under stress. This indicates that the high noise intensities (over $100 \mathrm{~dB}$ for maximum intensities) emitted by the animals during the temperature assessment may be due to other management practices, such as vaccination, cleaning of the facilities, and factors related to the maternal line.

Regardless of the environmental temperature found, because of the piglets' breed, their nutrition, and housing management, the squealing intensity is assumed to be the same in both environments. Piglets use Rev. Ciênc. Agrovet., Lages, SC, Brasil (ISSN 2238-1171) 
vocalization to call the sow so that they can feed when they are either hungry, afraid, in pain, or dissatisfied with the environment and when they are seeking adaptation to the environment. Vocalization is one of the ways piglets use to express their feelings, and it can be noted and taken as a parameter even in the early days after birth (HESSING et al. 1994). Vocalizations emitted by piglets in stressful situations are indicators of quality of life and/or an instant analysis of the emotional state of distressed animals (DÜPJAN et al. 2008). To maintain their temperature, the piglets seek places far from winds and water and huddle in their litters to increase their body surface temperature and decrease heat loss.

The noise levels found in this study exceeded those recommended for good occupational health. Workers exposed to loud noises over $90 \mathrm{~dB}$ tend to have difficulties in verbal communication and require greater attention to understand their activities, which can cause psychological tension. Additionally, high noise intensities impair the mental concentration needed to perform activities that require attention and agility, where two hours of noise exposure results in a significant decrease (KLATTE et al. 2013).

Analysis of the noises made by the animals and by the environmental enrichment devices revealed that both the cooled and uncooled facilities had noise levels that exceeded the recommended level, including the minimum intensities. According to the Brazilian Regulatory Standards (NR15, BRAZIL 2011), workers may be exposed to noises up to $85 \mathrm{~dB}$ for 8 hours a day, and important risks must be considered when the noise level is above this index. Thus, it is crucial to indicate the use of safety equipment such as hearing protection to prevent ear injuries in cases such as the one presented herein or in cases where the worker is involved with daily evaluations or handles pigs for more than 8 hours a day. However, the amount of time for these assessments was relatively short and did not expose individuals to hearing health risks.

The use of safety equipment such as hearing protection (PPE) is an efficient method to prevent problems related to noise emissions by pigs upon handling them in both of the environments in this study. NR 6 (BRAZIL 1992) describes PPE as a single-use product used by the worker exposed to noise, and the employer shall provide workers with PPE free of charge and in perfect condition, and the workers shall obey the employer's instructions on its proper use.

Impairment caused by the workers' and the confined animals' overexposure to noise leads to a decline in animal welfare which requires looking for efficient ways to reduce sound pressure, either by using PPE (VIEIRA 1997), improving or rethinking noise management in pig farming, or seeking less invasive methods that can be applied sustainably.

\section{CONCLUSION}

The installation of fans and rooftop sprinklers led to a decrease in temperature that provided ideal temperatures for the sow and piglet, which sought the creep for protection and heat. The noise made by the piglets upon restraint did not alter the acoustic environment, but the welfare of the animals may be compromised due to the high frequency.

The permanence of employees without the use of preventive equipment for swine management can cause damage to their health since the noise intensities found in these studies are higher than those stipulated by current legislation.

Swine management practices need to be reviewed in order to promote less invasive techniques which cause less discomfort to animals and workers, thereby favoring the entire pork value chain.

\section{REFERENCES}

BRAZIL. 1992. Regulatory Standard for Personal Protective Equipment - NR 6: Ordinance No. 6, of 19/08/1992. Available in: http: // www.tem.gov.br/temas/SegSau/Normas Regulamentadoras. Accessed in: May 2020.

BRAZIL. 2000. Consolidation of work law. Decree-Law No. 5,452, of May 1, 1943. Approves the consolidation of labor laws. Atlas, São Paulo. Available in: http: // www.tem.gov.br/temas/SegSau/Normas Regulamentadoras. Access in: May 2020.

BRAZIL. 2011. Ministry of Labor and Employment. NR nำ15: Unhealthy Activity and Operations. Available in: http: // www.tem.gov.br/temas/SegSau/Normas Reguladoras. Accessed in: Jun. 2020.

COLEMAN GJ \& HEMSWORTH PH. 2014. Training to improve stockperson beliefs and behaviour towards livestock enhances welfare and productivity. Revue Scientifique et Technique (International Office of Epizootics) 33: 131-137.

CORDEIRO AFS et al. 2012. Efficiency of distinct data mining algorithms for classifying stress level in piglets from their vocalization. Engenharia Agrícola 32: 208-216.

DÜPJAN S et al. 2008. Differential vocal responses to physical and mental stressors in domestic pigs. Applied Animal Behavioral Science 114: 105-115.

GIRALT JM. 2002. Valoración del estrés de captura, transporte y manejo en el corzo (Capreolus capreolus): efecto de la acepromacina y de la cautividad. Tesis (Doctor em Veterinaria). Barcelona: Universitat Autònoma de Barcelona. 63p.

Rev. Ciênc. Agrovet., Lages, SC, Brasil (ISSN 2238-1171) 438 
GONÇALVES CGO et al. 2009. Occupational exposition to noise in dentists of State Paraná: perception and effects onhearing. Revista de Odontologia UNESP 38: 235-243.

HESSING MJ et al. 1994. Individual behavioral and physiological strategies in pigs. Physiology \& Behavior 55: 39-46.

KLATTE M et al. 2013. Does noise affect learning? A short review on noise effects on cognitive performance in children. Frontiers in Psychology 4: 578.

KÖPPEN. 2011. Clima dos Municípios Paulistas. Informações sobre o Clima-Pirassununga, São Paulo. Available in: http://www.cpa.unicamp.br/outras-informacoes/clima-dosmunicipiospaulistas.html. Accessed in: 20 apr. 2011.

LEAL PM \& NÃ̃̃S IA. 1992. Ambiência animal. In: CORTEZ LAB \& MAGALHÃES PSG (Org.). Introdução à engenharia agrícola. Campinas: Unicamp. p.121-135.

MARCHANT JN et al. 2001. Vocalizations of the adult female domestic pig during a standard human approach test and their relationships with behavioral and heart rate measures. Applied Animal Behavioral Science 72: 23-39.

MARQUES AFS et al. 2016. Assessment of noise levels emitted by electro rural equipment used in the production of feed and fodder processing. Caderno de Ciências Agrárias 8: 1-6.

MOI M et al. 2014. Vocalization data mining for estimating swine stress conditions. Engenharia Agrícola 34: 445-450.

PMAC. 1994. Exposição ao ruído: Norma para a proteção de trabalhadores que trabalham em atividades com barulho. Revista Proteção 29: 136-138.

VIEIRA SDG. 1997. Análise ergonômica do trabalho em uma empresa de fabricação de móveis tubulares. Dissertação (Mestrado em Tecnologia). Florianópolis: UFSC. 25p.

WHO. 1999. WORLD HEALTH ORGANIZATION. Guidelines for community noise. Available in: http//:www.who.int/destore/peh/noise/guidelines2.html. Accessed in: 10 May 2020. 